\title{
POLITIK REPRESENTASI ISLAM DALAM FILM 212 THE POWER OF LOVE
}

\author{
Asep A. Sahid Gatara \\ FISIP, Universitas Islam Negeri (UIN), Sunan Gunung Djati, Bandung, Indonesia. \\ E-mail:asepsahidgatara@uinsgd.ac.id
}

\begin{abstract}
ABSTRAK.
Film merupakan media yang menggambarkan praktik wacana melalui penanaman kekuasaan dan ideologi. Oleh karena itu, film selalu berada dalam ruang persaingan praktik pendefinisian, pemosisian dan pengontrolan khalayak. Munculnya film-film religi bertema Islam di Indonesia juga tidak terlepas dari praktik wacana tersebut. Lebih dari satu dekade, film religi yang bercerita tentang Islam dan dinamikanya telah mampu memberikan warna bagi dunia perfilman dan juga bagi perkembangan Islam itu sendiri. Kajian dalam tulisan ini merupakan perluasan kajian tentang teks film yang bertujuan untuk mengidentifikasi, menganalisis dan merumuskan bagaimana Islam dalam konteks persaingan politik Indonesia direpresentasikan melalui narasi film. Korpus kajian adalah Film 212 the Power of Love yang memiliki latar belakang Aksi Bela Islam, 2 Desember 2016 (ABI). Islam yang dianalisis pada kajian ini mengkhususkan pada ekspresi keislaman tertentu, seperti sosial dan politik. Kajian ini menggunakan metode analisis wacana kritis dari Theo van Leeuwen yang menyajikan model exclusion dan inclusion. Kedua model analisis ini umumnya sama-sama mengandung potensi promosi dan marginalisasi. Kajian ini menunjukkan bahwa pertama, Film 212 the Power of Love menyajian wacana Islam apolitis $v s$ Islam apatis. Dan kedua, dengan wacana tersebut menjadi promosi atau legitimasi bagi semua pendukung $\mathrm{ABI}$ dan sekaligus marginalisasi bagi kelompok masyarakat anti $\mathrm{ABI}$.
\end{abstract}

Kata kunci: Film religi; Islam; politik representasi; wacana kritis

\section{POLITICS OF ISLAMIC REPRESENTATION IN FILM 212 THE POWER OF LOVE}

\begin{abstract}
.
Film is a media that describes the practice of discourse through the cultivation of power and ideology. Therefore, the film is always in the practice competition space of defining, positioning and controlling the audience. The emergence of Islamic-themed religious films in Indonesia is also inseparable from the practice of the discourse. More than a decade, the religious film that tells the story of Islam and its dynamics has been able to give color to the world of film and also to the development of Islam itself. This study is an extension of the study of film texts which is aimed to identify, analyze and formulate how Islam in the context of Indonesian political competition is represented through film narratives. Corpus of analysis is the Film 212 the Power of Love which has the background of Aksi Bela Islam, December 2, 2016 (ABI). The Islam analyzed in this study specializes in specific Islamic expressions, such as social and political. This study uses the critical discourse analysis method from Theo van Leeuwen that presents exclusion and inclusion model. Both of models of analysis generally contain the same potential for promotion and marginalization. This study shows that first, Film 212 the Power of Love presents apolitical vs. apathetic Islam. And Secondly, this discourse is the promotion or legitimacy of all ABI supporters and at the same time the marginalization of anti-ABI community groups.
\end{abstract}

Key words: Religious film; Islam; politics of representation; critical discourse

\section{PENDAHULUAN}

Sebagai sebuah media, film hadir menjadi aparatus sosial yang aktif menyuguhkan tontonan bagi khalayak umum. Dalam perspektif tersebut, media, termasuk film, bukan hanya sebagai sarana pengiriman informasi atau pesan, namun juga aktif sebagai aparatus pengirim pesan itu sendiri. Penyuguhan tontonan tersebut sesungguhnya adalah praktik peneguhan film tampil sebagai aparatus pembuat pesan. Oleh karena itu, film tidak hanya bertujuan untuk pemenuhan kepentingan tunggal, melainkan pemenuhan kepentingan yang sangat kompleks.

Salah satu pendorong kompleksnya tujuan kehadiran film adalah karena setiap film senantiasa diproduksi dalam latar kekuasaan tertentu. Oleh sebab itu, film acapkali digunakan atau difungsikan sebagai alat propaganda dan alat perluasan kepentingan politik tertentu, seperti pengukuhan kekuasaan (Irawanto, 2004). Di sini dapat dikatakan bahwa citra dan narasi dari setiap film adalah cermin untuk melihat dan memahami latar politik yang beroperasi di balik 
setiap kehadiran film.

Dengan demikian, melihat dan memahami film tidak cukup hanya dari aspek teknologi rekreasi, informasi, pertunjukan, seni dan budaya, namun juga dapat dilihat dari aspek ekonomi, sejarah, sosial, budaya, dan politik. Dari aspek yang disebut terakhir misalnya, kehadiran film dilihat dan dipahami tidak dalam ruang kosong, namun ia hadir dan bekerja dalam ruang aneka benturan dan pertarungan kekuasaan. Film lekat dengan dalil politik bahwa siapa mempertontonkan apa, untuk siapa, mendapatkan apa, kapan, dan bagaimana. Inilah politik film di mana arena tontonan harus selalu berhadapan dengan ragam politik lainnya.

Relasi film dan politik praktis misalnya digambarkan oleh Budi Irawanto dalam bukunya: Film, Ideologi, dan Militer:Hegemoni Militer dalam Sinema Indonesia (Irawanto, 2017). Buku ini berisi kajian semiotik atas tiga 'film sejarah', yakni Enam Djam di Jogja, Janur Kuning dan Serangan Fajar. Dalam buku ini peran militer digambarkan sebegitu paripurna, terutama ketika militer menjalin hubungan dengan masyarakat sipil. Secara bersamaan secara kontras sedang terjadi peminggiran peran kaum sipil (baik rakyat jelata maupun diplomat yang berjuang di meja perundingan) dalam usaha mempertahankan kemerdekaan. Hal serupa ketika pemutaran film G 30 S PKI di era Orde Baru dan era Reformasi, menegaskan relasi antara film dan politik.

Sejauh ini industri film di Indonesia sendiri mengalami pasang-surut, termasuk industri film religi. Namun demikian, dalam satu dasar warsa terakhir di era Reformasi ini, film religi sedang menunjukkan grafik naik, khususnya lagi adalah film religi yang bertemakan Islam (IslamicThemedFilms). Filmbertemakanataubernafaskan Islam ini misalnya, tentu dapat menjadi ruang masuk untuk membaca dan memahami mengenai dinamika ekspresi keislaman tertentu di Indonesia. Termasuk ekspresi pada kehidupan politiknya.

Dalam industri film di era Reformasi (era kebebasan dan keterbukaan), Islam dilihat sebagai pasar yang sangat menjanjikan seiring dengan semakin berkembangnya geliat ekspresi atau praktik kehidupan keislaman di Indonesia dan semakin terbukanya pengaruh keislaman dalam segala aspek keduniawian, termasuk dunia sosial dan politik. Dalam dunia politik misalnya, seiring dengan semakin kompetitif dan sekaligus semakin terpolarisasinya politik pasca era Reformasi, Islam bak "gadis" yang selalu diperebutkan (Effendy, 2000b). Oleh karena itu, Islam menjadi pusat perhatian, pemberitaan dan percakapan khalayak publik. Termasuk para khalayak penggemar dan produsen film.

Sejak era Reformasi mulai banyak diproduksi film bertemakan Islam. Film Ketika Cinta Bertasbih yang rilis pada tahun 2009 dan diadaptasi dari novel dengan judul yang sama karya Habiburrahman El Shirazy misalnya, cukup fenomenal karena memampu menarik jutaan khalayak penonton. Demikian juga Film Ayat-Ayat Cinta Bertasbih, 99 Cahaya di Langit Eropa, Assalamu'alaikum Beijing, dan lain sebagainya.

Dalam industri perfilman nasional, fenomenal film bertemakan Islam sebenarnya tidak hanya dilihat dari jumlah penonton semata, tetapi disimak juga dari aspek apresiasi khalayak publik. Antara lain misalnya, Film 212 the Power of Love. Film tersebut dipandang fenomenal seiring adanya kontroversial di kalangan khalayak pengamat dan penikmat film. Penayangan film ini mendapatkan penolakan di sejumlah daerah di Indonesia, seperti di Palangkaraya dan Manado. Hal itu karena film tersebut dianggap bermuatan politis dan berlatar belakang gerakan paham radikal (viva.co.id, 2018).

Selain itu, Film 212 menjadi fenomenal karena film ini tidak bisa terlepas dari latar kontestasi politik Pemilihan Gubernur DKI Jakarta 2017 dan promosi untuk Pemilihan Presiden dan Wakil Presiden 2019. Tidak bisa dielakan lagi, 212 identik dengan gerakan yang membela Islam karena telah dinistakan oleh salah satu calon Gubernur DKI Jakarta, Basuki Tjahaja Purnama atau Ahok, dan memiliki dampak politik yang berarti bagi pasangan penantangnya, yaitu Anies Baswedan dan Sandiaga Uno.

Film 212 itu menyajikan wacana-wacana tertentu, baik wacana yang melegitimasi maupun yang memarginalisasi. Misalnya, wacana Islam politik, Islam radikal, Islam barbar, wacana keimanan, damai dan cinta, dan wacana lainnya. Wacana-wacana tersebut dikonstruksi di atas teks dan konteks film yang tampak cenderung ditujukan untuk mengklarifikasi sekaligus menyerang balik lawan-lawan politik. Sejauh ini, Aksi Bela Islam yang berjilid-jilid, dengan puncaknya pada tanggal 2 Desember 2016, 
memang banyak dituduh sebagai gerakan politik praktis yang ditumpangi oleh kepentingan kelompok Islam garis keras atau Islam radikal di Indonesia.

Oleh karena itu, kemenangan pasangan Anies Baswedan-Sandiaga Uno adalah banyak disebut-sebut sebagai kemenangan gerakan Aksi Bela Islam 212, dan otomatis kemenangan Islam radikal. Dan sejauh ini, Islam radikal melekat dengan persepsi buruk di lapisan masyarakat. Kelompok Islam radikal identik dengan antiPancasila, anti-NKRI, intoleran dan mendirikan Negara Islam. Ini artinya, persaingan atau kontestasi politik DKI Jakarta tidak ada kata selesai hingga terpilih dan dilantiknya pasangan Anies Baswedan-Sandiaga Uno sebagai Gubernur DKI Jakarta. Bahkan lebih dari itu, corak kontestasi politik tersebut masih terasa hingga Pemilihan Presiden dan Wakil Presiden tahun 2019.

Secara khusus, kajian ini membahas tentang politik representasi Islam yang ditunjukkan dalam Film 212 the Power of Love melalui bahasa verbal maupun visual. Upaya analisis terhadap film itu diharapkan tidak hanya wacana tentang Islam dan dinamikanya, namun juga diketahui makna sosial yang terkonstruksi untuk bisa sampai ke khalayak. Film bertema keislaman tentu di dalamnya bersangkuatan dengan politik dalam Islam (politik Islam). Terutama politik dalam pengertian praktis maupun dalam pengertian pilihan nilai-nilai ajaran Islam.

Dalam sejumlah literatur menyebutkan bahwa politik Islam memiliki pijakan yang tidak tunggal sebagai titik tolak pemikiran dan praktiknya, melainkan beragam dan senantiasa berkembang. Ada politik Islam yang menekankan pada syari'ah dan akhlak pribadi, seperti pemikiran politik Islam klasik Al-Farabi (878-950), Al-Mawardi (meninggal 1058), dan Ibn Taimiyah (1263-1328) yang memiliki asumsi negara kerajaan. Di samping itu ada juga yang menekankan pada sistem, seperti, pemikiran modern Tjokroaminoto dengan konsep Sosialisme Islam (1924), dan pemikiran politik Abul A'la Al-Maududi dan Musthafa Husni As-Siba'i mempunyai asumsi negara republik dengan pemahaman mengenai sistem. Demikian juga Anwar Ibrahim yang berbicara mengenaI Masyarakat Madani (civil society) di belakangnya ada pemerintahan yang demokratis dan administrasi yang efesien, sehingga ada gambaran tentang suatu sistem (Kuntowijoyo, 1997). Hal yang sama pemikiran politik Islam kontemporer Kuntowijoyo (1997) yang menekankan sistem sekaligus meninggalkan pendekatan akhlak yang personal.

Pendektan syari'ah dan akhlak, menurut Kuntowijoyo (1997), sebenarnya sangat fundamental dalam Islam, tetapi menimbulkan kesan seolah-olah umat Islam hanya pandai berbicara hal-hal yang baik, tidak mau tahu tentang kenyataan. Pendektan itu dapat meyakinkan orang, sebab masih selalu tersisa pertanyaan how to do it. Selain itu, pendekatan syari'ah dan akhlak itu menyebabkan tidak tersentuhnya kenyataankenyatan sejarah, kekinian dan kesdisinian.

Bersamaan dengan meningkatnya produktivitas film religi, sebenarnya studi tentang film Indonesia bertemakan Islam ikut meningkat. Film-film betema Islam tersebut terutama mencuat pada era pasca reformasi. Fokus perhatiannya ada juga pada dimensi politik di balik film-film bertema Islam. Misalnya, Film Perempuan Berkalung Sorban. Film ini rilis tahun 2009 dan disutradarai oleh Hanung Bramantyo. Film yang dibuat berdasarkan novel yang ditulis oleh Abidah El Khalieqy bermuatan pandangan kritis tehadap sistem pesantren yang cenderung tidak berpihak pada perempuan akibat sosial budaya dan kuasa yang ada. Film ini mewakili pandangan atau kepentingan kelompok pluralis ataupun liberalis yang hendak mendobrak kejumudan kelompok Islam konservatif.

Kemudian kontestasi kepentingan politik juga melekat pada film religi seperti Film AyatAyat Cinta. Film ini rilis pada tahun 2008 yang disutradarai oleh Hanung Bramantyo. Film yang diambil dari novel best seller yang ditulis oleh Habiburrahman El Shirazy sejatinya menunjukkan tema percintaan, namun ternyata juga mempromosikan kekuatan Islam tertentu, yakni pembaharuan Islam konservatif. Namun dalam praktiknya, lebih mempromosikan Islam sebagai solusi terhadap segala aspek kehidupan manusia, termasuk masalah percintaan. Di sini Film Ayat-Ayat Cinta menempatkan Islam sebagai kekuatan dominan.

Hanya saja, sejauh pengetahuan penulis, kajian akademik yang komprehensif tentang film bertemakan Islam yang memiliki fokus perhatian tentang Islam dalam konteks kontestasi politik keindonesiaan kontemporer masih belum banyak ditemukan. 
Kajian-kajian terbaru tentang film bertemakan Islam misalnya dalam kajian Tomas Barker yang lebih banyak menonjolkan sebagai bagian dari bentuk baru budaya pop Islam dan fenomena munculnya kelas menengah baru Islam di Indonesia. Aspek yang menjadi titik perhatian dalam kajiannya adalah cara-cara bagaimana mereka menggambarkan sebuah habitus atau kebiasaan kelas menengah Muslim, seperti kebiasaan bepergian atau berpetualang ke luar negeri dan sibuk dalam menemukan pasangan, membangun keluarga, mengejar pendidikan tinggi, dan memiliki pekerjaan yang baik. Kebiasaan-kebiasaan kelas menengah baru Muslim itu diketahu sebagai rangkaian dari kehidupan salehnya (Barker, 2017). Hasil kajian Barker terhadap film bertema Islam menunjukkan bahwa identitas peran utama protagonis adalah mereka yang memiliki keimanan yang kuat, terutama ketika mereka berinteraksi dengan orang-orang asing di luar negeri yang mayoritas non-Muslim. Peran-peran protagonis tersebut menjadi identitas keislaman Indonesia yang ditonjolkan dalam film bertema Islam dalam konteks transnasional. Identitas keislaman warga Indonesia yang kuat di luar negeri dihadap-hadapkan dengan peran identitas antagonis masyarakat asing, baik yang samasama Muslim maupun yang non-Muslim.

Kajian terdahulu lainnya mengenai film bernafaskan Islam lebih berkaitan dengan komodifikasi Agama, seperti kajian yang dikerjakan oleh Hakim Syah. Ia menganalisis film AyatAyat Cinta, Ketika Cinta Bertasbih, dan Perempuan Berkalung Sorban, yang masingmasing diproduksi tahun 2007 dan 2009. Dalam kajiannya, Syah menemukan bahwa film Islam cenderung berada pada dua ruang secara bersamaan, yakni ruang idealisme dakwah dan ruang komodifikasi agama. Dalam ruang idealisme dakwah, film-film yang bertemakan Islam memiliki arti sebagai strategi dakwah yang dikelola melalui artefak budaya. Di sini menurut Syah, dakwah akhirnya harus "berkompromi" dengan teknologi sehingga aktualisasi dakwah bisa bergerak sesuai dengan dinamika sosial dan budaya. Sementara pada ruang komodifikasi agama, film-filmyang bertemakan Islamsebenarnya adalah komodifikasi agama oleh produksi massa melalu wujud budaya populer. Dalam hal ini Islam dikomodifikasi ketika kepercayaan dan simbol-simbolnya berubah menjadi barang yang bisa dijual dan dibeli demi keuntungan. Dalam konteks komodifikasi, film-film bertemakan Islam hadir untuk melegitimasi budaya populer di kalangan umat Islam, khususnya kaum muda Islam. Agama pada gilirannya dihadirkan hanya untuk memenuhi industri (pasar) yang menganut prinsip supply dan demand (Syah, 2013). Kajian Syah ini memiliki relevansi dengan studi penulis pada lokusnya, yakni film bertemakan Islam, namun berbeda dalam fokus perhatianya. Penulis memiliki fokus kajian pada aspek politik, dan di titik inilah tergambarkan signifikansi dari kajian penulis.

Adapun kajian yang terakhir dilakukan oleh Lukman Hakim (2015) yang menghubungkan produksi film bernafaskan Islam dengan antropologi Islam di Indonesia. Terutama dengan konsepsi Trikotominya Clifford Geertzmengenai "Agama Jawa", yakni Santri, Abangan, dan Priyayi. Trikothomi itu menurut studinya bisa menjelaskan hubungan agama, film, dan budaya di masyarakat Indonesia. Representasi Islam pada film-film religi itu cenderung bercorak Islam akulturatif, sinkretik ataupun simbolik (Hakim, 2015). Hakim menjelaskan bahwa agama (simbol-simbolnya) seringkali digunakan dalam film-film bergenre horor. Seperti kyai yang berperan mengusir setan, lantunan ayat-ayat alQur'an, tasbih yang diputar-putar kyai, dan lain sebagainya. Hal itu menurut Hakim bisa disimak pada film Sundel Bolong (nominasi ketiga film Indonesia tahun 1981), Nyi Blorong (Nominasi pertama tahun 1982), Kisah Cinta Nyi Blorong, Buaya Putih, dan Ratu Pantai Selatan (Hakim, 2015). Seperti halnya kajian sebelumnya, studi Hakim ini memiliki relevansi dengan kajian penulis dalam lokusnya

Dari ketiga kajian akademik di atas, teramati bahwa kajian tentang penggambaran Islam dalam film religi di Indonesia lebih banyak memberikan tekanan pada aspek budaya pop, aspek komodifikasi dan aspek antropologi. Sementara, kajian yang memberikan tekanan pada aspek politik representasi dan ekspresi keislaman masih jarang ditemukan. Hal demikian juga ketika dilihat dari konteks yang melatarinya, khususnya konteks peristiwa kontestasi politik keindonesiaan.

Politik representasi pada dasarnya merupakan strategi dan taktik siapa menghadirkan citra apa dari peristiwa apa, kapan (konteks), bagaimana, dan bertujuan apa. Politik representasi 
berpijak pada dalil bahwa sesunguhnya posisi film senantiasa berada dalam tarik menarik kekuasaan dan ideologi kebudayaan yang melatarinya.

Representasi itu sendiri menurut Stuart Hall adalah produksi makna melalui bahasa. Makna-makna diproduksi melalui bahasa dengan menggunakan kode-kode atau tanda-tanda yang mensimbolisasi atau merujuk pada objek, orang peristiwa atau hal-hal yang dianggap "the real word" (Hall, 2003). Dalam konteks itu, film merupakan sistem representasi hal mana politik (praktik-praktik) pemaknaan dilakukan. Ia berkerja seperti bahasa yang terdiri dari kodekode atau tanda-tanda yang berfungsi untuk memproduksi makna-makna. Sebagai ruang politik representasi, film adalah entitas yang diproduksi dalam keadaan tidak vakum. Dan, film merupakan teks sosial yang senantiasa memiliki kaitan dengan konteks sosial budaya di mana teks tersebut diproduksi, didistribusikan, dan dikonsumsi (Noviani, 2011)).

Berkenaan dengan operasi ideologi dan kekuasaan di balik setiap media, termasuk film, Stuart Hall mengatakan bahwa media adalah situs yang cukup signifikan untuk produksi, reproduksi maupun transformasi ideologi dan kekuasaan. Dalam konteks itu, apa yang diproduksi oleh media merupakan representasi realitas sosial sebagai jendela untuk memahami seperti apa realitas itu dan bagaimana ia bekerja. Film, oleh karenanya, bisa berfungsi sebagai pintu masuk utama untuk memahami isu-isu sosial, termasuk isu politik, yang berkembang di suatu masyarakat (Noviani, 2011: 23).

Islam pada konteks kajian ini adalah ekspresi keislaman atau praktik berislam yang aneka ragam. Ekspresi keislaman tersebut selalu dikaitkan dengan artibut atau predikat tertentu. Islam sejatinya dilihat sebagai Islam itu sendiri (Let Islam be Islam), Islam sebagai agama dan ajaran rahmatan lil 'alamin (rahmat bagi alam semesta), baik oleh orang "dalam" maupun "luar". Namun demikian, dalam perjalanannya Islam membentuk dan mempengaruhi wilayahwilayah keduniawian tertentu, seperti sosial, budaya, ekonomi, dan politik. Oleh karena itu, banyak otoritas kekuasaan atau pun rezim keilmuan tertentu, sebenarnya bukan menjadi kewenangannya, yang kemudian berusaha memberikan kategori-kategori atau klasifikasiklasifikasi Islam.

Di Indonesia, demikian juga di negaranegara lainnya yang bermayotitas umat Islam, pembicaraan mengenai Islam sering lebih kental warna politiknya. Menurut Bahtiar Effendy (2000) salah satu faktor yang membentuk wacana keislaman seperti itu adalah masih belum jelasnya posisi Islam dalam negara. Terutama posisi kehadiran umat Islam yang diakui (pengakuan) dalam kesejarahan dan pembangunan nasional. Sepanjang sejarah Indonesia merdeka, persoalan itu belum selesai dibicarakan.

Berkaitan dengan itu, banyak strategi yang dipilih dan digunakan umat Islam dalam upaya memperjelas posisinya dalam bernegara. Pilihan-pilihan strategi itu belakangan melahirkan atribut atau sebutan yang melekat pada setiap usaha perhimpunan dan pergerakannya. Menurut Kuntowijoyo (1997), paling tidak ada tiga strategi yang umumnya dipilih umat Islam, yakni strategi struktural, kultural dan mobilitas sosial. Strategi struktural menekankan formalisme syari'ah Islam melalui kekuasaan (bahkan acapkali ada paksaan dan kekerasan) menuju perubahan struktur politik. Perjuangan yang dilakukan dalam kelembagaan politik atau pun institusi kenegaraan. Strategi seperti ini melahirkan "Islam politik". Dalam kehidupan politik, Islam politik mengalami hubungan yang turun-naik dengan negara. Selama Orde Lama dan Orde Baru, Islam Politik ini lebih banyak ditekan dan dikucilkan. Misalnya sepanjang 19701990 kata-kata seperti "ekstrem kanan" , "NII", "mendirikan negara Islam", dan "anti-Pancasila" sangat gencar dituduhkan pada "Islam Politik. Hal yang hampir sama ketika di era Reformasi, terutama "Islam politik" diidentikan dengan "anti-Pancasila".

Kemudian strategi kultural menekankan perubahan perilaku individual dan cara berpikir. Kalau dalam strategi struktural syari'ah lebih menonjol, maka strategi kultural lebih menonjolkan hikmah. Hikmah di sini dalam pengertian cara yang baik. Cara-cara yang etis, beradab dan kultural. Strategi ini melahirkan "Islam kultural" atau "Islam ibadah". Islam dengan atribut ibadah ini bebas berkembang pada zaman Orde Baru. Terutama dalam bidang pendidikan dan dakwah.

Menurut Bahtiar Effendy (2000), hadirnya "Islam kultural" ini didasari pandangan bahwa "Islam politik" merupakan sesuatu yang sulit untuk dijual karena ingatan-ingatan pahit yang membekas pada diri para aktivis dan pelaku politik Islam di satu pihak dan negara di pihak lain. Untuk itu, kalangan ini lebih 
memilih bidang garapan transformasi sosial, dengan menawarkan Islam yang tidak begitu ideologis (menurut ukuran dasawarsa 1950an), tetapi sesuai dengan kebutuhan waktu tertentu. Dengan pandangan seperti itu, Nurcholis Madjid atau Cak Nur mengemukakan agenda desakralisasi; Abdurrahman Wahid atau Gus Dur menyuarakan isu pribumisasi atau Islam sebagai faktor komplementer; Dawam Rahardjo menekuni pembangunan masyarakat pedesaaan melalui pesantren; dan Munawir Sjadzali mempromosikan pentingnya melihat Islam dalam konteks Indonesia.

Adapun strategi mobilisasi sosial menekankan perubahan struktur sosial dengan menggerakan kaum menengah terpelajar dan usahawan Muslim. Strategi mobilisasi sosial ini menghindari politik praktis, ia lebih mempersiapkan sumber daya manusia melalui sinergi IPTEK (Ilmu Pengetahuan dan Teknologi) dan IMTAQ (Iman dan Taqwa). Sekalipun ternyata memililiki dampak politik yang berarti. Pilihan strategi ini melahirkan "Islam aqidah". Islam bukan sebagai kekuatan politik ataupun ibadah semata, melainkan kekuatan transformasi dan mobilitas sosial. Strategi ini misalnya dipilih dan dikembangkan oleh Ikatan Cendekiawan Muslim se-Indonesia (ICMI) yang berdiri tahun 1990. Islam dengan sebutan Islam aqidah ini, seperti halnya Islam ibadah, mendapatkan tempat istimewa dalam lingkaran kekuasaan negara (Kuntowijoyo, 1997).

Dalam perkembangannya, dari ketiga atribut atau sebutan pada Islam itu, dua atribut yang sering diperhadap-hadapkan atau saling berkontestasi, yakni "Islam politik" dan "Islam kultural". "Islam politik" sering dipandang terlalu legalistik atau formalistik, sementara "Islam kultural" dinilai terlalu kompromistik. Padahal keduanya adalah hanya berbeda dalam pilihan strategi, sementara tujuannya sama, yaitu memperjelas posisi Islam dalam bernegara dan mendapatkan pengakuan dan sekaligus perlakukan adil dari negara.

\section{METODE}

Korpus kajian ini adalah teks film religi Indonesia bertema Islam yang diproduksi dalam latar Aksi Damai Bela Islam, 2 Desember, belakangan dikenal dengan aksi 212. Berkaitan dengan aksi tersebut, film ini mengangkat judul
212 the Power of Love. Pemilihan film ini sebagai sumber data kajian didasarkan pada ketersediaan dokumentasi film, luasnya perdebatan publik, serta kelarisan film pada saat launching. Hal itu misalnya berdasarkan jumlah penonton dan pemberitaan pro-kontra luas dari sejumlah media. Film tersebut dianalisis menggunakan metode analisis wacana kritis dari The van Leeuwen. Metode analisis ini menjadi langkahlangkah untuk mengungkapkan, mengidentifikasi dan merumuskan bagaimana politik representasi Islam dipraktikkan, dan bagaimana Islam dikonstruksi secara diskursif di dalam teks film.

Dalam analisis wacana kritis, wacana tidak dipahami semata sebagai studi bahasa. Di sini analisis wacana menggunakan bahasa dalam teks untuk dianalisis bukan (hanya) dari aspek kebahasaan, namun juga mengkaitkan dengan konteks. Konteks di sini berarti bahasa itu digunkan untuk tujuan dan praktik tertentu, termasuk di dalamnya praktik kekuasaan (Eriyanto, 2011).

Selain itu, analisis wacana dalam analisisnya lebih bersifat kualitatif dibandingkan analisis isi yang umumnya kuantitatif. Oleh sebab itu, analisis wacana lebih memperhitungkan pemaknaan teks daripada penjumlahan unit kategori seperti dalam analisis isi. Dasar dari analisis wacana adalah interprestasi, karena analisis wacana merupakan bagian metode interpretatif yang mengandalkan interpretasi dan penafsiran peneliti. Pretensi analisis wacana adalah pada muatan, nuansa, dan makna yang laten dalam teks media (Eriyanto, 2011), termasuk media film.

Teks yang menjadi pijakan wacana dalam film 212, dan sekaligus menjadi korpus kajian, adalah teks dalam bentuk dialog, adegan-adegan dan simbol-simbol yang merepresentasi Islam. Teks-teks tesebut dikumpulkan dan dipilih dengan melihat relevasinya pada kajian ini. Yaitu, teks-teks yang berkaitan dengan bagaimana Islam damai dipromosikan dan bagaimana Islam kontra damai dimarginalisasikan. Teks-teks yang telah dipilih kemudian dianlisis dengan mengandalkan interpretasi dan penafsiran peneliti.

Adapun interpretasi dan penafsirannya, secara praktis berpatokkan pada dua perhatian utama analisis van Leeuwen, yaitu: (a) exclusion (eksklusi) atau proses pengeluaran aktor sosial, (b) inclusion (inklusi) atau proses pemasukan aktor sosial. Kedua model analisis 
ini umumnya sama-sama mengandung potensi untuk dapat membongkar praktik marginalisasi atau pengucilan dan penindasan, termasuk yang bersifat rasis, terhadap suatu individu atau aktor sosial dan kelompok sosial tertentu oleh kelompok sosial lainnya. Dalam bahasa Leeuwen, suppression and backgrounding. Baik proses eksklusi maupun inklusi secara tidak langsung bisa mengubah pengetahuan dan pemahaman masyarakat terhadap suatu isu dan melegitimasi posisi pengetahuan dan pemahaman tertentu (Van Leeuwen, 2008).

Dalam praktiknya, digunakan serangkaian ragam strategi wacana bagaimana strategi wacana itu dapat dipakai sedemikian rupa sehingga mempengaruhi makna yang sampai ke khalayak pembaca atau penonton. Di antara strategi wacana itu adalah strategi abstraksi, kategorisasi, identifikasi, dan asosiasi. Strategi wacana tersebut umumnya digunakan dalam model analisis inklusi. Sementara strategi wacana yang sering digunakan dalam model analisis eksklusi adalah strategi pasivasi dan nominalisasi.

Model eksklusi dengan strategi wacana yang dipakainya, seperti menyembunyikan atau menghilangkan aktor sosial dalam pemberitaan atau percakapan, berakibat macam-macam yang diantaranya dapat melindungi subjek/pelaku dalam suatu proses penayangan. Dan, model inklusi dengan strategi wacana yang digunakan, seperti aktor tidak dihilangkan dalam dialog dan adegan, proses marginalissai seseorang atau kelompok tertentu tetap bisa dilakukan (Eriyanto, 2011).

Politik representasi Islam dalam Film 212 the Power of Love terkait dengan model eksklusi dan inklusi melalui ragam strategi wacana di atas. Ada sejumlah aktor atau subjek dalam Film 212 tersebut, yaitu, peserta Aksi Bela Islam, individu dan kelompok anti Aksi Bela Islam, elit politik, media massa, dan warga non-muslim. Ada dua unit analisis yang disajikan, yakni dimensi teks, dimana teks (kata, kalimat, informasi atau susunan bentuk kalimat tertentu dan lain sebaginya) sebagai rekaman posisi aktor sosial, baik individu, kelompok maupun institusi, dalam peristiwa dan berfungsi mengkomunikasikan fakta dan makna atau pengetahuan tertentu. Selain itu, teks tersebut berkaitan dengan aktor sosial atau peristiwa yang dihilangkan ataupun yang dimasukan dalam teks itu sendiri. Dan, unit analisis yang kedua adalah dimensi strategi wacana yang dipakai dengan menggunakan teks dan berefek makna atau pengetahuan seperti apa pada khalayak. Inter-relasi antara teks dan konteks sosial-politik secara luas akan dikaji dan dimati pada tahap ini.

\section{HASIL DAN PEMBAHASAN}

Bagian ini memaparkan politik representasi Islam yang diwacanakan melalui film 212 the Power of Love. Pemaparannya meliputi wacana yang disajikan, yakni Islam apolitis vs Islam apatis. Keduanya merupakan variasi dari atribut atau kategori Islam yang disampaikan oleh Bahtiar Effendy dan Kuntowijoyo di bagian pendahuluan. Selain itu, meliputi aktor-aktor dan peristiwa Aksi Bela Islam yang dipromosikan serta dimarginalisasikan melalui kedua wacana tentang Islam tersebut.

\section{Deskripsi Umum}

Teks Film 212 the Power of Love dapat disimak melalui beberapa alur cuplikannya, baik dalam teks dialog maupun dalam adegan dan gambar-gambar. Di sini, alur cerita berkaitan dengan aktor-aktor dan peristiwa yang melatarinya. Ceritanya dimulai dengan scane dialog Rahmat (Fauzi Baadilla) sebagai jurnalis dengan rekan-rekan dan pimpinan kerjanya di kantor redaksi majalah Republik. Dialog berisi tentang artikel yang ditulis Rahmat pada laporan utama majalah yang menyatakan bahwa agama telah didegradasi sebagai kekuatan atau senjata politik. Dalam kejadian penistaan agama, Rahmatmenulis laporan bahwa seharusnya Islam itu bukan seorang anarkis yang menggunakan mayoritas untuk menyerang minoritas. Hal inilah yang kemudian menjadi rangkaian konflik awal film, Rahmat dinilai tidak cinta agamanya sendiri. Rahmat percaya bahwa agama kerap diperalat politisi. Rahmat menuding aksi-aksi "bela Islam" yang marak di Jakarta pada 20162017 lalu telah ditunggangi politisi. Hal itu terlihat misalnya pada gambar 1 .

Kemudian diceritakan bahwa karena kesibukan Rahmat sebagai jurnalis membuat dirinya jarang pulang kampung ke Ciamis, Jawa Barat. Namun, pada satu ketika, ibunya meninggal dunia di kampung, Rahmat harus pulang kampung. Ada satu alasan di mana Rahmat tidak pernah pulang ke Ciamis. Dan, ternyata, Rahmat belum pernah pulang ke rumah selama 10 tahun. 
Pada bagian cuplikan ini, kehidupan pribadi Rahmat mulai terungkap. Dia punya ayah seorang Kyai yang meninggalkannya di pesantren saat dia masih kecil. Di situlah awal masalah kenapa Rahmat dengan tegas mengatakan "Bagi gua, bokap gua udah mati." Dia hanya menganggap ibunya yang sayang padanya karena ibunya yang mengunjunginya di pesantren. Dia juga tidak pernah bertegur sapa bahkan berbincang dengan ayahnya.

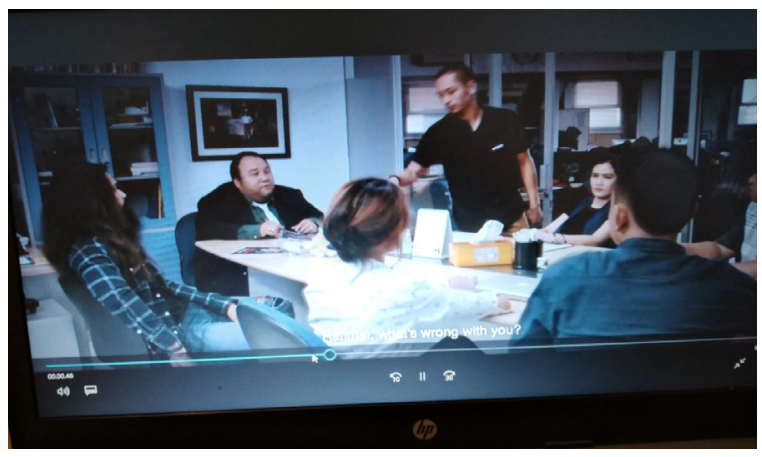

Gambar 1. Rahmat dan Pimpinan beserta Tim Redaksi Majalah Republik berdebat masalah artikel tentang Aksi Bela Islam 411 yang telah terlanjur dimuat

Rahmat dan ayahnya, Kyai Zainal tidak harmonis karena beliau memandang Rahmat adalah anakyang pengecutdan tidak bertanggung jawab. Perseteruan antara Rahmat dan ayahnya Kyai Zainal yang masih menganggap peradaban dan kehidupan selayaknya di masa lalu. Sementara Rahmat, memiliki pola pikir, ilmu pengetahuan dan peradaban harus maju sesuai dengan masa modern, tanpa meninggalkan nilainilai atau ajaran yang positif.

Hasilnya, mereka berdua selalu berbeda pendapat. Ketika hendak kembali ke Jakarta, Rahmat mendengar kabar bahwa ayahnya akan tergabung dengan demonstran yang akan melakukan aksi long march pada tanggal 2 Desember 2016.

Karena Rahmat tidak setuju dengan aksi ini, dia berusaha keras mencegah ayahnya pergi. Tapi ayah Rahmat tidak mau menuruti dan bersikeras pergi juga long march. Jadilah rombongan Jamaah Ayah Rahmat berangkat dari Ciamis ke Monumen Nasional (Monas), Jakarta dengan jalan kaki. Mengingat ayahnya sudah tua dan sakit-sakitan, Rahmat juga akhirnya ikut serta rombongan dengan mengambil jarak dari rombongan long march. Selain itu, isu yang menjadi kekhawatiran Rahmat adalah aksi ini disusupi pihak jahat dan provokator yang mengambil keuntungan dengan memicu kerusuhan.
Diksi "the Power of Love" dalam film ini adalah ketika masa aksi atau jamaah berhasil memutihkan Monas, dan juga memulihkan hubungan Sang Kyai dengan anaknya. Jutaan jamaah hadir di Monas untuk melancarkan Aksi Bela Islam karena sikap cinta kepada agama (Allah Swt dan Al-Qur'an). Saat kejadian, aksi tersebut benar-benar berjalan lancar, cenderung penuh solidaritas pada kaum non muslim, saling membantu, tertib dan menunjukkan bahwa aksi ini memang aksi damai, bukan aksi kekerasan. Bahkan Rahmat sendiri akhirnya ikut larut dalam Aksi Bela Islam 212.

\section{Islam Apolitis vs Islam Apatis}

Wacana tentang Islam apolitis dimaksudkan bahwa Aksi Bela Islam 212 adalah gerakan umat Islam yang terbebas dari muatan politik apapun. Hal itu sesuai dengan arti dari kata apolitis itu sendiri, yakni tidak berminat pada politik, atau tidak bersifat politis (Sugono, 2011). Jadi Islam apolitis adalahekspresikeislamandalamberbagai gerakan yang tidak memuat minat pada politik. Di sini politik diartikan sebagai kursi kekuasaan negara. Islam apolitik merupakan variasi dari kategori Islam sebagaimana yang disampaikan di atas, terutama kategori Islam kultural. Kategori Islam kultural apolitis ini pernah digunakan oleh Akhmad Rizqon Khamami ketika mengamati fenomena pertarungan politik antara dua tokoh Islam di Turki, Erdogan dan Gulen. Kategori Islam kultural apolitis tersebut diidentikan dengan Gulen, sementara Erdogan diidentikan dengan Islam politik. Di luar keduanya adalah identik sekuler, seperti yang melekat pada Kemal Ataturk (Khamami, 2016).

Dalam Film 212 the Power if Love, kata apolitis tidak dihadirkan secara tersurat melalui kata atau kalimat, namun hanya secara tersirat melalui kata politik. Hal itu misalnya bisa dilihat dari potongan dialog di bawah ini:

Reporter: Ini aksi apa

Kyai Zaenal: Aksi ini bukan aksi tentang politik, kita menunjukkan bahwa kita cinta kepada Allah Swt dan Al-Qur'an.

Dari dialog yang digunakan dalam Film 212 itu terlihat bahwa Islam itu senantiasa menanamkan rasa cinta kepada Allah swt dan kepada al-Qur'an. Oleh karena itu, ketika Allah Swt dihina atau al-Qur'an dinistakan oleh siapapun, termasuk oleh pejabat negara, 
maka umat Islam yang baik itu adalah mereka yang melakukan pembelaan melalui aksi massa. Sebaliknya, umat Islam yang buruk adalah mereka yang terdiam seribu bahasa ketika Allah Swt dihina atau al-Qur'an dinistakan. Bahkan mereka semakin buruk ketika tidak hanya diam seribu bahasa namun mereka malah menuduh macam-macam terhadap Aksi Bela Islam, seperti tuduhan adanya misi Islam radikal dan bermuatan politik di balik aksi.

Dialog di atas seolah menjadi jawaban dari para penggerak dan simpatisan Aksi Bela Islam 212 terhadap sejumlah pihak yang menuduh bahwa Aksi Bela Islam 212 merupakan gerakan politik, atau setidak-tidaknya gerakan yang ditunggangi oleh kekuatan-kekuatan politik tertentu. Aksi Bela Islam 212 dikatakan sebagai suatu gerakan yang sengaja diciptakan untuk membendung derasnya dukungan terhadap Ahok sebagai calon Gubernur pada Pilgub DKI Jakarta 2017. Ahok dinilai akan mencederai hati umat Islam jika terpilih sebagai Gubernur karena ia adalah non Muslim.

Teks potongan dialog itu secara umum menggambarkan perilaku peserta Aksi Bela Islam 212 yang penuh cinta kepada agamanya karena itu mereka senantisa bertindak damai selama di perjalanan sehingga mengundang simpatik dari masyarakat yang dilalui peserta aksi, terutama peserta aksi yang long march dari Ciamis menuju Monas. Bahkan banyak yang menilai aksi long march tersebut, yang memakan waktu berhari-hari dan mendapatkan pemberitaan yang berkali-kali, telah berhasil menggetarkan dan sekaligus menggerakan hati umat Islam lainnya, tidak hanya umat di sekitar Jakarta dan Jawa Barat namun juga hampir seluruh penjuru nusantara, untuk ikut serta bergerak ke Monas dalam rangka mendukung dan menjadi bagian dari Aksi Bela Islam 212.

Wacana yang sama terlihat juga pada ucapan yang disampaikan oleh kordinator lapangan (Korlap) melalui megaphone mini kepada seluruh calon peserta aksi long march bahwa "Hari ini, kita akan melakukan perjalanan panjang ke Jakarta dalam rangka aksi damai". Kalimat ini mengeksklusi subjek politik dan menginklusi subjek damai. Ini artinya, melalui susunan kata itu Film 212 ingin mempromosikan atau menyampaikan bahwa Aksi Bela Islam 212 adalah murni aksi damai dan sekaligus memarginalisasi terhadap segala tuduhan negatif yang selama itu mengiringinya.

Sementara itu, wacana tentang Islam apatis dimaksudkan sebagai sikap acuh tidak acuh, tidak peduli, masa bodoh umat Islam yang berlebihan terhadap segala pergerakan, perhimpunan dan perubahan dalam Islam itu sendiri. Kata berlebihan bisa mengarah pada sikap/sifat yang cenderung menimbulkan rasa curiga atau tidak percaya. Wacana Islam apatis itu dialamtkan kepada semua orang yang anti atau menolak Aksi Bela Islam 212. Hal itu terlihat dalam dialog berikut ini.

Rahmat: Ngaku tentara Allah, bawa pesan damai, tapi kelakuan kaya orang barbar (sambil mengumpat dan sinis).

Sekelompok PesertaAksi: Apa yang kamu omongkan.... (sambil mau mengeroyok)

Isna: Stop, stop kang, dia itu Muslim, dia apatis pada Islam karena dia tidak tahu. Lantas karena itu kita berhak mengkafirkan dan menghakimi dia?

Dialog di atas terjadi ketika Rahmat sampai di Monas, yang sebelumnya ikut rombongan long march dari Ciamis, langsung meliput peristiwa Aksi Bela Islam 212 yang telah dipenuhi oleh jutaan umat peserta aksi. Di selasela peliputannya, Rahmat bertemu dengan sekelompok peserta aksi. Dalam pertemuannya itu, Rahmat hampir dikeroyok karena ketahuan menjadi salah satu jurnalis yang memojokan Aksi Bela Islam sebelumnya dalam pemberitaan majalah Republik. Selain itu, Rahmat telah mencing emosi kelompok peserta aksi dengan kata-kata umpatan. Hal itu terlihat misalnya pada gambar 2 .

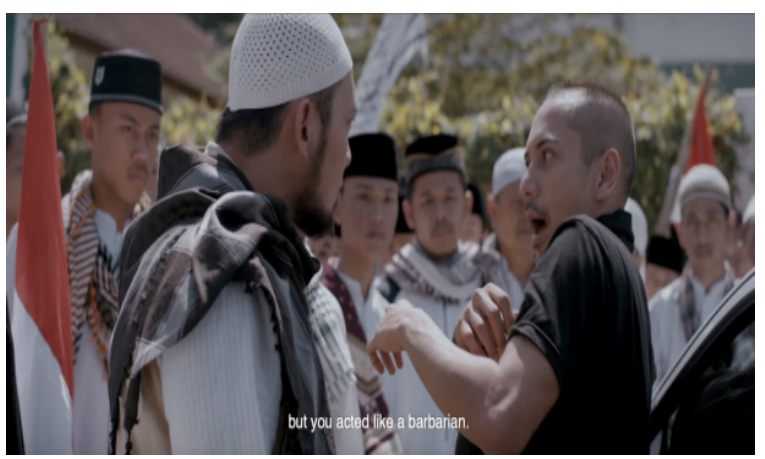

Gambar 2. Percekcokan antara Rahmat dengan oknum peserta Aksi

Berdasarkan gambar dan dialog itu, peserta Aksi Bela Islam digambarkan mendapatkan tudingan sebagai barbar dan takfiri atau suka 
mengkafirkan kelompok-kelompok Islam di luar kelompknya. Selain itu, dalam artikel yang ditulis Rahmat menyebutkan bahwa Aksi Bela Islam adalah aksi Islam radikal dan politis. Umpatan dan tulisan artikel Rahmat seperti itu mewakili ataupun menggambarakan para pihak yang selama ini menolak Aksi Bela Islam. Melalui dialog itu, mereka diwacanakan dalam Film 212 sebagai kelompok umat Islam yang apatis. Kenapa apatis? Karena mereka tidak tahu tentang Islam yang sesungguhnya. Wacana Islam apatis ini cendrung menjadi kepanjangan dari wacan Islamophobia. Wacana yang sempat membesar di Eropa dan Amerika Serikat. Islamophobia merujuk pada rasa takut atau khawatir sekelompok komunitas, terutama komunitas non Muslim, yang berlebihan dan tidak berdasar terhadap Islam dan segala dimensinya.

Terkait dengan sikap takfiri ini, lepas dari tuduhannya benar atau tidak, dalam kehidupan emirisnya telah menjadi salah satu indikator atau ciri Islam radikal. Dalam kategorisasi Islam, kelompok ini memang cenderung menganut teologi eksklusif dan banyak digunakan oleh sejumlah kelompok Islam garis keras untuk menghakimi agama-agama lain atau kelompokkelompok Islam lain yang tidak sejalan dengan ajaran Islam yang mereka yakini sebagai kebenaran sejati. Golongan Islam yang merespon terhadap gejala eksklusivitas beragama tersebut adalah munculnya Neo-Modernisme Islam (Suryani, 2016). Atau dalam kategorisasi Kuntowijoyo (1997), sebagai Islam aqidah.

\section{Promosi dan Marginalisasi Aktor}

Dalam Film 212 the Power of Love dinarasikan bahwa individu dan kelompok individu tertentu yang antiAksi Bela Islam 212 melakukan tudingan yang menyakitkan dan tidak berdasar terhadap Aksi Bela Islam. Film 212 secara umum menggambarkan sikap perilaku individu anti Aksi Bela Islam yang buruk, sinis, berandalan, dimanfaatkan setan dan tidak cinta Islam. Hal itu melekat pada sosok Rahmat, sebagai pusat aktor atau aktor utama yang ada di film tersebut. Hal itu misalnya terlihat pada potongan ungkapan berikut ini:

Kyai Zaenal: Sadar ga kamu Rahmat, bahwa otak mu sudah dimanfaatin setan.

Ungkapan itu menunjukkan bahwa aktor anti Aksi Bela Islam adalah mereka yang tidak sadar dan pikirannya dirasuki atau dikendalikan setan. Oleh karena itu, pikirannya dipenuhi oleh prasangka yang buruk pada orang lain atau kepada kelompok masyarakat tertentu. Dalam kehidupan empirik, setan adalah musuh seluruh umat manusia yang tugasnya mengoda mannusia dan menjerumuskan ke lembah dosa dan kelak ke neraka.

Film 212 ini menampilkan (inklusi) Rahmat sebagai pentolan anti-Aksi Bela Islam yang asal tuduh bahwa Aksi Bela Islam adalah gerakan Islam radikal dan ditunggangi para politisi. Sebaliknya, Film 212 ini mengeluarkan (eksklusi) perilaku pihak kelompok Islam Garis Keras atau Islam Radikal sebagaimana dituduhkan kelompok Anti-Aksi Bela Islam dari tayangan atau adegan. Demikian juga, film ini mengeluarkan para politisi yang terkenal dari tayangan. Baik politisi yang sedang berkontetasi pada Pilgub DKI Jakarta 2017 putaran kedua, pasangan Anies Baswedan-Sandiaga Uno dan Pasangan Basuki Tjahaja Purnama-Djarot Saeful Hidayat, maupun para politisi yang akan bertarung, baik sebagai pasangan calon maupun sebagai pengusung dan pendukung, di Pilpres 2019. Selain itu, dalam Film 212 tersebut tidak secara lugas menampilkan dan menyebutkan nama orang yang memicu munculnya Aksi Bela Islam. Di sini yang disebutkan hanya aktor "si penista agama". Sebagaimana disebutkan di atas, penghilangan aktor-aktor tersebut adalah berdampak macam-macam. Dalam hal ini misalnya berdampak, pertama melindungi para politisi yang terlibat dalam akasi di satu fihak, dan menyembunyikan tensi kontestasi yang masih terasa di fihak lain. Kedua, mempromosikan bahwa Aksi Bela Islam itu terbebas dari motivasi dan pesan-pesan politik tertentu.

Dalam Film 212 tersebut tidak tergambar, misalnya, apa saja yang dilakukan oleh si penista agama, dan juga apa saja yang dilakukan oleh para elit politik yang terlibat langsung selama rangkaian Aksi Bela Islam. Film ini berfokus pada usaha marginalasiasi aktor-aktor anti Aksi Bela Islam. Modelnya adalah inklusi peristiwa dengan strategi wacana yang dipakai adalah asosiasi. Strategi ini dipakai untuk mengatakan bahwa aktor itu tidak bekerja sendirian, melainkan dihubungkan dengan kelompok yang lebih besar. Rahmat misalnya diasosiasikan dengan paham Marxisme dan budaya liberal Barat. Ini menarik karena terjadi upaya menyatukan 
sesuatu kutub yang berjauhan bahkan bertentangan (liberalisme dan marxisme) dalam satu sosok Rahmat.

Sekilas kelihatan danya ketidakjelasan ideologi seperti apa yang sebenarnya Rahmat maksud, namun bersamaan terus berjalannya adegan demi adegan film, kemudian diketahui belakangan bahwa ia adalah seorang marxis dengan diperlihatkan bagaimana ia kerap mengutip Karl Marx dalam dialog-dialognya, serta pada satu adegan di mana layar komputernya yang memperlihatkan ia tengah mencari gambar Marx di google images. Peristiwa itu berlanjut pada satu kesempatan pertemuan redaksi dalam majalah tersebut.

Nampaknya, kegamangan cerita film ini dalam mendefinisikan sekaligus memposisikan kategori Islam liberal dan paham marxisme menjadi pangkal utama dengan adanya penggabungan Harvard University sebagai ikon liberalisme dengan Karl Marx sebagai ikon marxisme. Mengenai Karl Marx itu bisa dilihat pada gambar 3 .

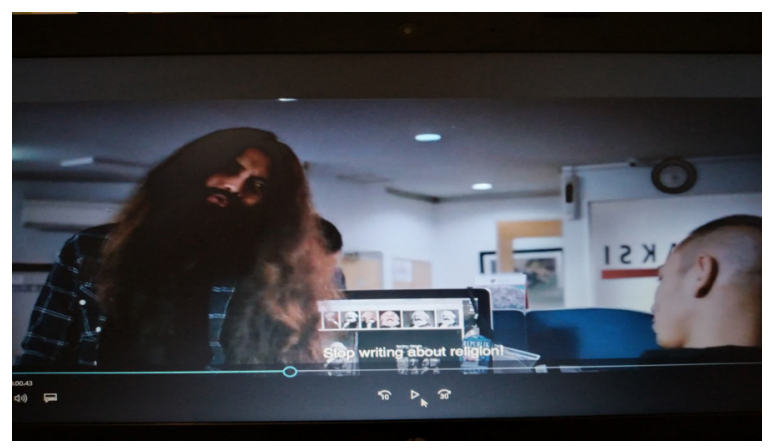

Gambar 3. Rahmat dan foto-foto Karl Marx yang dikaguminya

Dari gambar itu terlihat Rahmat sedang bersitegang dengan sahabat satu-satunya, Adhi. Dalam adegan itu, Adhi menegur Rahmat dengan nada keras mengenai tulisan Rahmat yang bertendensi memojokan Aksi Bela Islam. Bahwa aksi itu sudah ditunggangi pemain-pemain politik. Menanggapi teguran keras sahabatnya itu, Rahmat terlihat malah 'cuek' dengan terus menyimakgambar Karl Marx di laptop kerjanya dan sesekali hanya berkata bahwa ia tidak akan menomorduakan ideologinya ketika menulis.

Sementara itu, mengasosiasikan Rahmat dengan budaya liberal adalah melalui identitas perguruan tinggi tempat Rahmat kuliah, yakni Harvard University, Amerika Serikat. Hal itu bisa diliha dari potongan dialog berikut ini: Tokoh ulama: Dulu sekolah apa, ngambil apa?
Rahmat: Saya dulu di Harvard, Amerika, tahu kan?

Berdasarkan dialog di atas, terlihat ketus dan sombongnya Rahmat ketika mengaku lulusan Harvard University, USA. Mengasosiasikan Rahmat dengan USA dan foto Karl Marx adalah upaya mewacanakan bahwa selama ini yang anti Aksi Bela Islam adalah, selain apatis dan tidak tahu tentang Islam, berlatar Marxisme dan Liberalisme. Di Indonesia keduanya masih dianggap negatif karena bertentangan dengan Pancasila.

Marxisme selama ini misalnya masih dianggap sebagai sumber ajaran untuk Komunisme dan Partai Komunis. Komunisme itu dilarang di Indonesia setelah terbentuk wacana bahwa ideologi mereka anti-Tuhan, antiagama, dan pernah melakukan pembantaian terhadap umat beragama. Pelarangan faham atau pembubaran PKI berdasarkan melalui TAP MPRS Nomor XXV/MPRS/1966 tentang Pembubaran PKI, Pernyataan sebagai Organisasi Terlarang di Seluruh Wilayah Republik Indonesia bagi PKI, dan Larangan setiap Kegiatan untuk Menyebarkan atau Mengembangkan Faham atau Ajaran Komunisme/Marxisme-Leninisme.

Dalam kajian pemikiran politik Indonesia, salah satu varian dari ajaran Marx tersebut, selain komunisme, adalah sosialisme. Ajaran yang banyak dipandang bersumber atau berasal dari pengaruh asing, terutama pengaruh Barat (western influence). Selain sosialisme, termasuk sosial-demokratik dan sosialisme Islam, berkembang juga leninist. Partai Komunis Indonesia (PKI) adalah penjelmaan dari leninist, sedangkan Partai Sosialis Indonesia (PSI) menjadi bagian dari penjelmaan sosial-demokrat (Manan, 2016).

Oleh karena itu, Film 212 the Power of Love tampak hendak melakukan marginalisasi secara halus terhadap semua kelompok anti Aksi Bela Islam (yang diwakili sosok Rahmat), termasuk terhadap semua kelompok anti Islam lainnya. Bahwa mereka adalah Marxis (atau Komunis) dan Liberalis. Dengan asosiasi seperti itu, mereka diharapkan bisa terkucilkan dalam tata kenegaraan dan sekaligus dalam kewargaan.

Upaya ini dilakukan melalui dan dalam Film 212 the Power of Love dapat dilihat sebagai pertahanan sekaligus sebagai serangan balik atas segala cap atau tuduhan yang disematkan kepada semua pendukung Aksi Bela Islam, 
termasuk para alumninya, kepada kelompokkelompok anti Aksi Bela Islam. Seperti tuduhan radikal, teroris, anti Pancasila, anti NKRI dan lain sebagainya.

\section{Eksklusi Latar Peristiwa}

Selain eksklusi sejumlah aktor, film ini juga melakukan eksklusi peristiwa politik yang sesungguhnya menjadi konteks film. Praktik eksklusi konteks pada film 212 itu seolah mengafirmasi kebiasaan praktik peminggiran konteks dan ideologi pada setiap film Indonesia bertema politis, termasuk film religi Islam yang bertema politis. Misalnya film Serangan Fajar dan film G30S/PKI seperti disebutkan sebelumnya.

Film 212 the Power of Love lebih menunjukkan film beradegan drama hubungan emosional ayah dan anak, ketimbang menunjukkan film bertema Islam dengan latar politik. Adegan konflik sang ayah dan anak yang berani melawan orang tua karena mempunyai ideologi berbeda dengan semua orang di seluruh ruang film tersebut. Oleh karena itu, Pilkada DKI Jakarta 2017 yang secara kasat mata terlihat berdekatan dengan peristiwa itu dikaburkan, tindakan penistaan terhadap agama oleh Gubernur DKI Jakarta, Ahok, disembunyikan, dan begitu pula isu adanya dugaan makar malah dimarginalisasikan.

Padahal dalam sejumlah kajianmenjelaskan bahwa kemenangan pasangan Anies Baswedan dan Sandiaga Salahuddin Uno pada Pilkada DKI Jakarta 2017 tidak bisa lepas dari peristiwa rangkaian Aksi Bela Islam, khususnya Aksi 212. Median Survey Institute misalnya, sebagaimana dikutip Putri (dalam (Djuyandi \& Ramadhani, 2019), menyebutkan bahwa aksi masa 212 dipercaya menjadi salah satu kekuatan yang menentukan kemenangan Anies BaswedanSandiaga Uno.

Gerakan 212 pada awalnya adalah bentuk penyampaian kemarahan umat Islam terhadap sikap Gubernur DKI, Basuki Tjahaja Purnama yang melakukan penistaan terhadap Islam, namun kenyataannya berdampak pada arena kehidupan politik, termasuk Pilkada DKI 2017. Sebab itu, latar Pilkada tersebut menjadi berkaitan dengan politik identitas. Dalam hal ini, politik yang mengekspolarsi identitas Muslim dan Non-Muslim. Aksi 212 tersebut juga muncul sebagai kombinasi pandangan konservatif dan sikap rasional komunitas Muslim (Djuyandi \& Ramadhani, 2019).

Meskipun judulnya menggunakan jargon yang diusung gerakan Aksi Bela Islam di Monas, khususnya aksi super damai 212, namun ternyata ia tidak menjadi sentral latar film. Di sini, aksi Bela Islam II (4 November atau 411) dan Aksi Bela Islam III (2 Desember atau 212) hanya ditampilkan sesaat melalui berita di televisi.

Film ini tidak mengungkap atau memunculkan alasan mengapa jutaan umat Islam melakukan aksi di Monas. Demikian juga, sasaran aksiitutidakjelas. Siapayangmelakukan penistaan agama. Hanya ada petunjuk samar bahwa umat Islam aksi karena pernyataan seorang pejabat negara yang dianggap "menghina Islam". Dalam filmitu, nama pejabat penyelenggara negara yang dituduh menghina Islam pun tidak dimunculkan. Di sini, selain adanya praktik eksklusi konteks, juga sebenarnya secara spesifik disertai praktik eksklusi aktor sosial.

Berdasarkan itu, Film 212 the Power of Love dapat dikatakan minim konteks. Hal itu tentu bukan tanpa disengaja atau tanpa tujuan. Berpijak pada uraian sebelumnya, sebenarnya dapat segera dicerna bahwa tujuan utama film 212 ini adalah untuk mempromosikan bahwa Aksi Bela Islam 212 bukan masalah kekuasaan politik dalam kontestasi Pilkada DKI 2017, melainkan murni sebagai bentuk kecintaan dan ketaatan seluruh umat Islam terhadap Allah Swt dengan semua Firman-firmannya, khususnya Al-Qur'an. Maka aksi 212 sering juga dikatakan sebagai aksi bela Al-Qur'an.

Dikarenakan adanya praktik pengkaburan atau penghilangan latar belakangnya, maka film 212 dapat dikatakan tuna konteks. Akibatnya, setiap wacana yang dimunculkan serta dipromosikan pun dalam film 212 tersebut cenderung menjadi "semu" atau "palsu" karena ahistoris ataupun akonteks. Di sini wacana yang hadir hanya berbasis pada teks-teks film. Padahal lahirnya wacana itu sejatinya dari adanya relasi kuat antara teks dan konteks.

\section{Penanaman Makna yang Ahistoris}

Secara sepintas segala pesan dari dialogdialog dan adegan-adegan di atas, wacana Aksi Bela Islam yang apolitis, dapat sampai ke khalayak penonton sebagai makna atau pengetahuan. Namun demikian tidak akan semudah membalikan tangan karena publik umumnya 
tahu bahwa Aksi Bela Islam adalah gerakan politik. Hal itu bersamaan dengan besarnya porsi pemberitaan media massa, dan juga publikasi sejumlah kajian akademik, yang mengkaitkan Aksi Bela Islam dengan kontestasi politik Pilgub DKI Jakarta 2017. Dengan demikian, upaya penyajian wacana tersebut menjadi ibarat dalam bahasa Sunda "nyumput dinu caang", yang artinya sembunyi di ruang terang benderang. Ingatan publik tentang peristiwa Aksi Bela Islam dan Pilgub DKI Jakarta sulit untuk mudah dihapus.

Mewacanakan Aksi Bela Islam adalah gerakan Islam apolitis dapat dikatakan ahistoris karena mobilisasi massa yang besar adalah bagian dari pilihan politik. Aksi Bela Islam 212 misalnya oleh Vedi R Hadiz dikategorikan gerakan politik Populisme Islam (Hadiz, 2016). Meskipun yang hadir pada Aksi Bela Islam itu beragam kelompok atau multikelas, bahkan ada dari luar kelompok gerakan Islam seperti kelompok miskin perkotaan dan kelompok non Muslim, namun mayoritas adalah kelompok Islam politik, baik garis keras maupun garis moderat. Bahkan mereka yang multikelas dalam aksi diikat oleh terminologi ummah (community of believers). Ummah tersebut sebagai representasi the people.

Ini artinya, Islam sesungguhnya tidak bisa lepas dari politik. Kategori Islam politik yang dirujuk pada ekspresi keislaman yang berhubungan dengan kekuasaan dan institusi negara adalah historis. Politik dalam Islam itu sendiri, telepas dari pendekatan yang digunakan, baik dalam pengertian praktis maupun dalam pengertian pilihan nilai-nilai, menggambarkan kontestasi pengaruh antara golongan umat Islam, yang berlangsung sejak zaman sahabat Khulafaur Rasyidin (Abu Bakar Ash-Shiddiq, Umar bin Khattab, Utsman bin Affan, dan Ali bin Abi Thalib) hingga saat ini. Kontestasi pengaruh tersebut tidak hanya berlangsung dalam ranah teologi seperti keyakinan atau kepercayaan, namun juga berkembang pesat dalam ranah kekuasaan dan kedudukan publik. Sebab itu, tentang bagaimana menghadirkan Islam pada Film 212 juga otomatis menjelaskan tentang sejarah panjang politik dalam Islam yang memang berkelindan satu periode dengan periode lainnya. Tentu dengan variasi-variasi khas yang melekat pada setiap periodenya tersebut.
Selain itu, sejarah panjang politik dalam Islam tidak hanya tergambar pada kontestasi pemikiran atara umat Islam, namun juga tergambarpadarelasi Islam(politik Islam)dengan negara. Di Indonesia misalnya, hubungan antara keduanya sangat dinamis atau turun-naik. Selama era Orde Lama dan awal Orde Baru, hubungan keduanya cenderung bersifat antagonistik. Islam dinilai dan diposisikan sebagai ancaman negara sehingga Islam berada pada situasi marginal, atau secara politik adalah minoritas dan outsider. Dalam ungkapan getir M Natsir, sebagaimana dituturkan oleh Mohammad Kamal Hassan, bahwa pemerintah telah memperlakukan Islam seperti kucing kurap (Effendy, 2000a).

Adapun di akhir masa Orde Baru, relasi keduanya menjadi cenderung bersifat harmonis atau akomodatif. Di mana sejumlah kepentingan Islam banyak diakomodir oleh negara. Hubungan harmonis tersebut tampak semkin kuat ketika berdirinya Ikatan Cendekiawan Muslim Se-Indonesia (ICMI) pada tahun 1990. ICMI lahir yang karena adanya mobilitas sosial (kelas menengah terpelajar dan usahawan) adalah gerakan akidah, bukan organisasi politik sekalipun ternyata mempunyai dampak politik yang berarti. Oleh karena itu, ICMI disebut oleh Kuntowijoyo sebagai Islam akidah, suatu kategori yang berbeda dari Islam politik dan Islam ibadah (Kuntowijoyo, 1997).

Dewasa ini semua kategori Islam seperti di atas memiliki kesamaan dalam mengusung Islam itu damai dan mendamaikan. Islam itu damai dalam konteks politik kontemporer sedang dicitrakan oleh partai-partai Islam atau pun partaipartai berbasis umat Islam di Indonesia. Partai tersebut tengah mentransformasikan fundamentalisme Islam, yang sebelumnya memang banyak dialamatkan ke partai Islam seperti PKS, menuju moderatisasi Islam (Geraldy, 2019). Sejauh ini, mayoritas elit dan kader Parati Islam hendak mencitrakan partainya sebagai Islam moderat atau Islam damai. Kehendak seperti itu dapat dilihat dalam konteks gejala dinamika hubungan Islam dan politik atau dengan kekuasaan dan negara. Ada hubungan yang antagonistik, ada pula hubungan yang akomodatif (Gatara \& Sofhian, 2012).

Gambaran Islam damai ditampilkan lewat dialog dalam film. Misalnya terdapat pada potongan dialog Adi dan Rahmat. "Islam itu peace and love, rahmtana lil'alamin. Yang 
radikal itu otak lo." Diksi peace and love memiliki makna bahwa Islam tidak hanya indah, tetapi juga damai dan penuh cinta. Sedangkan potongan dialog rahmatan lil'alamin, menunjukkan bahwa Islam merupakan agama yang membawa rahmat dan kesejahteraan bagi seluruh semesta alam.

Selain damai, Aksi Bela Islam hendak dicitrakan sebagai gerakan yang mengedepankan inklusivitas. Hal itu sebagaimana ditunjukkan adanya penghormatan dan penjagaan peserta aksi bela Islam terhadap umat Nasrani yang tengah melaksanakan ritual nikah di sekitar pusat aksi damai. Hal itu misalnya terlihat pada gambar 4 di bawah ini:

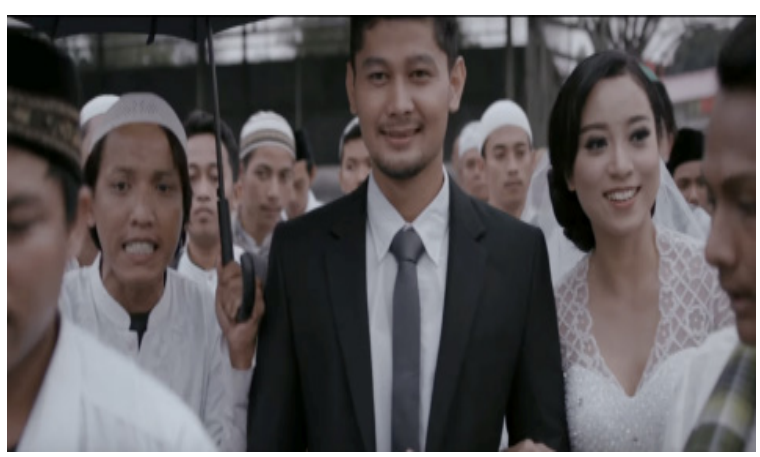

Gambar 4. Aksi simpatik peserta aksi bela Islam dalam menjaga dan menghormati ritual agama lain

Gambar potongan adegan film 212 di atas tengah mempromosikan juga tentang kategori Islam Indonesia yang mayoritas dengan karakter sesungguhnya, yakni bisa berdampingan dengan agama-agama lainnya. Di samping itu, Muslim Indonesia yang mayoritas, selain bisa berdampingan, juga bisa melindungi penganut agama-gama minoritas di Indonesia.

Selanjutnya, tipe Islam yang dianggap tidak baik ditampilkan dalam dan melalui adegan kekerasan lewat tindakan aksi sejumlah oknum peserta aksi damai bela Islam 212 terhadap Rahmat di tengah-tengah kerumunan aksi. Mereka dimarginalisasi melalui predikat golongan Islam radikalis atau Islam garis keras, sebagaimana terjelaskan pada adegan gambar 2 di atas.

Mereka yang melakukan kekerasan terhadap Rahmat, dengan berbagai simbol peci haji dan serban yang melekat, digambarkan dalam film itu hanyalah sekelompok atau segelintir orang yang menganut paham Islam garis keras. Kelompok ini ditampilkan dalam film secara terpisah dari kerumunan besar peserta aksi.
Wacana yang hendak dimunculkannya adalah bahwa segelintir Islam garis keras tersebut tidak sama sekali mewakili dari jutaan umat Islam peserta aksi 212 yang memadati Monas dan sekitarnya.

Dalam adegan itulah mereka sedang dimarginalisasi atau dipinggirkan dari jamaah besar peserta aksi. Bahwa para pelaku kekerasan itu adalah oknum semata. Dengan marginalisasi itu, secara bersamaan terpromosikan Aksi Bela Islam 212 sesungguhnya adalah sebagai aksi super damai dan terbebas dari kekerasan dan kepentingan politik.

\section{SIMPULAN}

Analisis terhadap teks Film 212 the Power of Love menunjukkan adanya politik representasi Islam dengan menyajikan wacana Islam apolitis dan wacana Islam apatis. Islam apolitis cenderung diwacanakan lewat aktor-aktor yang selalu mengekspresikan kedamaian, kecintaan dan kepercayaan tanpa minat kekuasaan. Sementara Islam apatis diwacanakan lewat aktoraktor yang suka mengekspresikan kegaduhan, tuduhan-tuduhan tak berdasar, selalu memiliki prasangka buruk, dikendalikan setan, liberal, dan marxis. Wacana Islam apolitis tersebut disajikan dan dipakai untuk mempromosikan atau melegitimasi kelompok-kelompok masyarakat yang didefinisikan sekaligus diposisikan sebagai kawan pergerakan dan perhimpunannya. Sedangkan Islam apatis disajikan dan digunakan untuk melakukan marginalisasi atau pengucilan terhadap kelompokkelompok masyarakat yang didefinisikan dan diposisikan sebagai lawan dalam pergerakan dan perhimpunannya. Di sini Islam tidak lagi dilihat hanya sebagai ajaran tetapi juga dilihat sebagai kekuatan. Oleh karena itu wajar bila muncul kategori-kategori Islam yang tidak semestinya, dan belakangan cenderung digunakan sebagai instrumen perangkul dan pengumpul di satu pihak, dan secara bersamaan menjadi istrumen pemukul dan penghancur di pihak lain. Padahal Islam sejatinya dilihat, meskipun tidak mudah, sebagai Islam itu sendiri, Let Islam be Islam. Islam sebagai agama pembawa rahmat bagi segala kepentingan makhluk.

\section{DAFTAR PUSTAKA}

Barker, T. (2017). Travels and Travails: Cosmopolitan Muslims in Indonesian. 
https://cinemapoetica.com/travels-andtravails-cosmopolitan-muslims-inindonesian-cinema/Diakses pada 16 September 2018

Djuyandi, Y., \& Ramadhani, R. (2019). The Effectiveness of Political Identity in Post 212 Movement. Central European Journal of International \& Security Studies, 13(4), 456-468.

Effendy, B. (2000a). (Re) politisasi Islam: pernahkah Islam berhenti berpolitik? Bandung: Mizan.

Effendy, B. (2000b). Islam di Tengah Polarisasi Politik. In H. M.Akkas, M.Amin dan Noer (Ed.), Kehampaan Spiritual Masyarakat Modern: Respon dan Transformasi NilaiNalai Islam Menuju Masyarakat Madani. (pp. 202-208). Jakarta: Media Cita.

Eriyanto. (2011). analisis wacana: pengantar analisis teks media. Yogyakarta: LKiS Yogyakarta.

Gatara, A. S., \& Sofhian, S. (2012). Pendidikan kewarganegaraan. Bandung: Fokusmedia. Aziz Saefudin.

Geraldy, G. (2019). Ideologi dan Partai Politik: Menakar Ideologi Politik Marhaenisme di PDIP, Sosialisme Demokrasi di PSI dan Islam Fundamentalisme di PKS. Politicon: Jurnal Ilmu Politik, 1(2), 134157.

Hadiz, V. R. (2016). Islamic populism in Indonesia and the Middle East. Cambridge: Cambridge University Press.

Hakim, L. (2015). Agama \& film: pengantar studi film religi buku perkuliahan Program S-1 Jurusan Komunikasi Dan Penyiaran Islam Fakultas Dakwah IAIN Sunan Ampel Surabaya. Surabaya: IAIN Press.

Hall, S. (2003). Representation: Cultural Representations and Signifying Practices (S. Hall (ed.)). London: SAGE Publication s Ltd.
Irawanto, B. (2004). Film propaganda: Ikonografi kekuasaan. Jurnal Ilmu Sosial Dan Ilmu Politik, 8(1), 1-16.

Irawanto, B. (2017). Film, ideologi, \& militer: hegemoni militer dalam sinema Indonesia: analisis semiotik terhadap Enam Djam di Jogja, Janur Kuning, dan Serangan Fajar. Yogyakarta: Warning Books.

Khamami, A. R. (2016). ERDOĞAN VERSUS GÜLEN: Perebutan Pengaruh antara Islam Politik Post-Islamis dengan Islam Kultural Apolitis. Al-Tahrir: Jurnal Pemikiran Islam, 16(2), 247-266.

Kuntowijoyo. (1997). Identitas politik umat Islam. Bandung: Mizan.

Manan, F. (2016). Sosialisme Islam: Perspektif Pemikiran Politik HOS Tjokroaminoto. JWP (Jurnal Wacana Politik), 1, 24-37.

Noviani, R. (2011). Konsep diri remaja dalam film Indonesia: analisis wacana atas film remaja Indonesia tahun 1970-2000-an. Jurnal Kawistara, 1(1), 43.

Sugono, D.(2011). Kamus Besar Bahasa Indonesia. In Jakarta: Gramedia Pustaka Utama dan Departemen Pendidikan Nasional.

Suryani, S. (2016). Neo Moderisme Islam Indonesia: Wacana Keislaman dan Kebangsaan Nurcholish Madjid. JWP (Jurnal Wacana Politik), 1(1), 29-40.

Syah, H. (2013). Dakwah dalam Film Islam di Indonesia (Antara Idealisme Dakwah dan Komodifikasi Agama). Jurnal Dakwah, 14(2), 263-282.

Van Leeuwen, T. (2008). Discourse and practice: New tools for critical discourse analysis. Oxford: Oxford University Press.

viva.co.id. (2018, May 16). "Film 212 The Power of Love Banyak Ditolak Penayangannya." Viva.Co.Id. https:// www.viva.co.id/showbiz/film/1036694film-212-the-power-of-love-banyakditolak-penayangannya/diakses pada 10 September 2018 